Journal of Qualitative Criminal Justice \& Criminology

\title{
Book Review | The Black \\ Child-Savers: Racial \\ Democracy \& Juvenile \\ Justice
}

Robin D. Jackson ${ }^{1}$

${ }^{1}$ Sam Houston State University

Published on: Apr 01, 2013

Updated on: Aug 17, 2020

License: Creative Commons Attribution 4.0 International License (CC-BY 4.0). 
Geoff K. Ward. The Black Child-Savers: Racial Democracy \& Juvenile Justice. University of Chicago Press, 2012; 336 pp.; ISBN: 9780226873183.

Drawing on biographical details, people's experiences, and historical documents, Geoff K. Ward examines Black child savers' efforts and struggles to transform a Jim Crow juvenile justice system into a racially democratic model of juvenile justice. In his first book: The Black Child-Savers: Racial Democracy \& Juvenile Justice, Ward describes Black child-savers as concerned Black Americans and their allies who sought racial reform in the juvenile justice system and who intervened on the behalf of Black dependent and delinquent youth. Ward also discusses "the sociocultural origins and organization of Jim Crow juvenile justice as well as the social movement by generations of Black Americans to replace the White supremacist parental state with an idealized racial structure of democratic social control" (p. 5).

In his introduction, Ward describes the racial history of juvenile justice as being similar to a quilt; the methodology used for this book consists of identifying and piecing together vital elements and historical accounts of race in America and in juvenile justice. Ward's discussion of the racial history of the juvenile justice system is organized chronologically and is broken into two main parts. Part One provides readers with an overview of juvenile justice and discusses the socio-historical origins and organization of Jim Crow juvenile justice. It also highlights the role that racial group power, White supremacist ideology, and related institutional structure played in dictating liberal rehabilitative ideals. In Chapter One, Ward examines the juvenile rehabilitative ideal and provides readers with a brief historical overview of the development of the juvenile justice system while exposing the root cause of racial injustice for Blacks in the juvenile justice system Ward moves from discussing the foundations of Jim Crow juvenile justice and Black youths' experiences in the nineteenth century American juvenile justice system to examining Progressive era Black youth's and communities' experiences in the emerging juvenile court in chapters 2 through 4 . Part One concludes with a discussion of the "social mechanisms and implications of Jim Crow juvenile justice" (p. 105).

Part Two of the book focuses on black child-savers and their impact on the racial history of American juvenile justice. Chapters within this section focus on black social status, oppositional politics, social movement resources, and the waves of reform led by Black child-savers. The first wave of the Black child-savers movement discussed in Chapter Five is characterized by self-help and racial uplift. This wave consisted mainly of under resourced Black women's benevolent associations who, along with Black civic leaders and the community, pooled resources to develop rehabilitative institutions for Black youth. Chapter Six discusses the second wave of the Black child-savers movement, which was characterized by a more professional approach that used civil rights organizations (i.e. NAACP), 
pressure group politics, legal challenges, and labor force integration. In Chapter Seven, Ward juxtaposes racial juvenile justice developments in Southern cities against changes in Harlem during 1954-1970 in order to examine integration efforts and changes in racial politics of juvenile justice. Ward closes the book with the argument that although Black child-savers achieved formal integration, contemporary juvenile justice continues to divide youth along racial lines by separating them into categories of deserving and undeserving of rehabilitation, with Black and other nonwhite youth characterized as undeserving.

In making the case for his book, Ward contends that earlier works on child-savers, such as Anthony Platt's The Child Savers: The Invention of Delinquency (1969) as well as the works inspired by Platt's book, overlook race in the child-saving movement. The purpose of Ward's book is to reexamine the childsaving movement with Black Americans at the center of the analysis in order "to understand the significance of race in American juvenile justice, historically and today" (pg. 6). Ward's examination of the role of race, specifically for Blacks in American juvenile justice, is well written and sheds much needed light on the experiences of Black youths in the juvenile justice system; it highlights how Black adults helped shape the American juvenile justice system. Because the book is an historical analysis, it devotes limited attention to contemporary causes of the disproportionate amount of Black and other nonwhite youths in juvenile and adult detention, jails, and prison facilities. Instead, Ward expertly uses the lives of Black child-savers and the efforts of Black organizations such as the NAACP to illustrate the role that slavery, Emancipation, reconstruction, White supremacy, segregation, the Great Migration, and civil rights movements play in the racial history of the American juvenile justice system. In the final chapters of the book, when Ward addresses contemporary racial issues in the juvenile justice system, he does so to demonstrate how early racial issues in the American juvenile justice system continue to be relevant today.

Unlike a vast amount of previous research into juvenile justice and the child-saving movement which tends to gloss over racial issues, The Black Child-Savers is unique in that it provides readers not only with insight into the role of race in the juvenile justice system, it also places Black Americans as participants and agents of change within the juvenile justice system. Readers more interested in contemporary race issues in the juvenile justice system and ways to resolve those issues may find the book somewhat lacking, because it does not provide as extensive an examination into race in the juvenile justice system after the 1970s as it does for earlier time periods. This could be viewed as a potential weakness of the book. However, in addition to filling gaps in the literature, the book also provides the background and context needed to begin a scholarly and well informed discussion of race and juvenile justice. This serves as a strength of the book and also demonstrates The Black Child-Savers' importance in laying the groundwork for future examinations into racial inequality in the American juvenile justice system. 
The Black Child-Savers is an amazing and well-written account of an understudied area of the juvenile justice movement and would be enjoyed by a wide range of groups. However, it is best suited for postgraduate scholars in criminology, social justice, civil rights, American history, and law. The Black Child-Savers is an essential read for the aforementioned groups because along with providing a detailed and more complete historical account of the juvenile justice system, the lessons learned from the experiences of Black youth and Black child-savers that are discussed in the book continue to be instructive and relevant to attaining racial justice in the juvenile justice system today.

\section{References}

Platt. A. M. (1969). The child savers: The invention of delinquency. Chicago, IL: University of Chicago. 